\title{
Leilah Assumpção, os muros e o dia branco
}

Fernanda Ribeiro Queiroz de Oliveira ${ }^{1}$

\section{Crítica é nome feminino, quem se lembra?}

Maria de Lourdes Torres de Assunção, conhecida no meio artístico como Leilah Assumpção, é nome de mulher e isso, por si, basta para que uma rede de pré-conceitos, referências cristalizadas, se constitua. A expectativa do senso comum é que ela retrate "coisas sensíveis", "metafísicas", "crises conjugais", definidas de maneira misógina como restritas ao leitor/expectador feminino, que tenha a superficialidade natural de quem não tem o tônus necessário para escrever obras "universais". Há um mercado editorial baseado nisso e na ideia de que mulheres autoras não são uma boa primeira opção, o que impede que os leitores sejam expostos o suficiente às obras escritas por mulheres. Essa é uma das razões para que a obra de Leilah Assumpção não tenha ocupado, ainda, o lugar de destaque não só diante da crítica especialista, mas do grande público de leitores. ${ }^{2}$

Ser mulher é quase um confinamento editorial forçado a falar de "coisas de mulher" para mulheres, reduzindo as autoras e segregando aquelas que não pertencem a essas expectativas. Livros de receitas, algo próximos da autoajuda ou, ainda, sobre filhos, vendem muito, ganham espaço em programas de tevê, são abraçados pelo mainstream. Algo que se distancie disso, seja pela complexidade da abordagem, seja pelo abandono dos temas "autorizados", convoca a uma luta muito maior para publicar, ser lida, ser vista. No cinema, na literatura, no teatro, na arquitetura, nas artes plásticas, os nomes masculinos desfilam dentro de qualquer produção como se fosse natural sua presença ali e a das mulheres algo acidental, pontual, porque é assim que as coisas são. Mesmo na moda, os nomes que povoam o imaginário do senso comum são masculinos. Um ou outro nome de mulher se levanta, transforma-se em símbolo de luta e liberdade, mas confina-se no indivíduo e não atinge o grupo. Há muito a ser feito para que a igualdade de condições diante do público leitor, da

\footnotetext{
${ }^{1}$ Doutora em letras e linguística e professora do Instituto Federal de Brasília (IFB), Samambaia, DF, Brasil. E-mail: fernandarqo@gmail.com

${ }^{2}$ Este artigo é decorrente de pesquisa realizada no âmbito das atividades de pós-doutoramento em letras e linguística na Universidade Federal de Goiás.
} 
plateia, do mercado, realmente se efetive nos mecanismos de recepção, uma vez que, nas palavras de Ana Lúcia Vieira de Andrade e Ana Maria de Bulhões Carvalho Edelweiss (2008, p. 21), assim que as mulheres começaram a se autorrepresentar é que se conseguiu perceber "o quanto as imagens do feminino divulgadas pela cultura, construídas a partir de oposições binárias, isto é, a partir de contraposições a um conceito de masculino" foram aprisionadoras de comportamento.

A dificuldade de publicação de peças de teatro pelas editoras já é grande; e quando são escritas por mulheres, então, a dificuldade é ainda maior. Laura Castro de Araújo $(2007, \text { p. } 2)^{3}$ observa que, em relação às dramaturgas, "este interesse é menor ainda, pois não se trata de falta de produção, mas critérios duvidosos do mercado editorial, que privilegiam os autores (em geral, homens) que possuem visibilidade na mídia e certo reconhecimento pela crítica teatral dominante." Em seu estudo, a pesquisadora apresenta dados segundo os quais $75,1 \%$ das peças teatrais publicadas entre 1990 e 2005 foram escritas por homens. Historicamente, a sociedade patriarcal impede que mulheres publiquem seus trabalhos, prejudica sua divulgação e contribui para que sejam ignoradas ou ridicularizadas pela crítica especializada. Júlia Lopes de Almeida (1862-1934) direcionou seu trabalho para o teatro e, juntamente com ele, um embrião de temáticas femininas, mas até recentemente não havia recebido espaço na história do teatro. Em Margem e centro, Ana Lúcia Vieira de Andrade (2006, p. xix) estabelece esse processo na clave das configurações sócio-históricas coletivamente traçadas, em que o canône autorreferenciado e predominantemente masculino possa ser modificado com o tempo a partir de novas configurações sociais. É aqui que as teorias feministas emergem como força propulsora para o desmonte da invisibilidade tanto das dramaturgas quanto de um olhar sobre as personagens femininas feito por mulheres. Em outro trabalho, a autora, juntamente com Ana Maria de B. C. Edelweiss, esclarece que a figura feminina tem sua presença "permitida" quando é construída para satisfazer um fetiche masculino e que as mulheres tinham espaço nas artes até o século XX apenas se não propusessem uma ruptura com as expectativas aprisionantes do olhar masculino (Andrade e Edelweiss, 2008, p. 17-18).

\footnotetext{
${ }^{3}$ Neste trabalho coloco o nome inteiro das autoras citadas, visto que a entrada apenas pelo sobrenome torna ainda mais problemática a visibilidade de nomes femininos, tanto no meio acadêmico ou fora dele.
} 
Apesar de Sábato Magaldi (2004), Anatol Rosenfeld (2014), Alexandre Mate e Pedro M. Schwarcz (2012) terem feito a concessão de falar sobre as autoras de teatro e elogiarem Leilah Assumpção, em suas obras de referência a respeito da história do teatro e seus autores, são os homens que ganham espaço e projeção. No livro Teatro Brasileiro: ideias de uma história, Jacó Guinsburg e Rosangela Patriota até levantam o nome de Hilda Hilst, Leilah Assumpção, Consuelo de Castro, mas são poucas linhas, apenas as mencionando. A obra reitera o percurso historiográfico de usar apenas as fontes já estabelecidas pelo cânone da crítica. E o que se faz necessário é honrar a memória das autoras buscando-as nos becos esquecidos dos registros oficiais, resgatá-las, trazê-las à luz, redimir a história de ter excluído as marginais do eixo homem-branco-hétero, fazer a arqueologia dos textos escondidos, não publicizados, "resgatar sua historicidade", como bem afirma Sandra Pellegrini (2007, p. 289).

As atrizes já recebem a adoração e respeito do público, afinal, estão em uma posição alinhada com o senso comum de que mulheres combinam perfeitamente com a expressão emocional, a extravasação de sentimentos e o drama. Lúcia Regina Vieira Romano (2009, p. 148-150) argumenta que "a história do teatro ocidental é uma história norteada pelos valores de uma sociedade heterossexual e sexista, que direciona quem deve fazer teatro, como e para quem" e que essa dinâmica de método é ineficiente, já que se justifica a presença das mulheres em cena por seu "talento nato para o jogo e o mascaramento, ou em razão de sua capacidade de - gerar vidas ou - compreender o outro.

Dominar o processo de criação e direção, comandar o roteiro, é terreno cheio de muros para as autoras, inclusive os impostos por seus colegas de profissão, que assumem uma posição de seus "mestres", mas relutam em aceitá-las em posição de igualdade, já que, aqui, os símbolos da racionalidade, ordenação e comando ainda estão cercados pela hegemonia masculina.

$\mathrm{O}$ resgate das autoras tem sido feito por uma esmagadora maioria de pesquisadoras. O sinal de atração maior, sendo mulheres, é que construam o equilíbrio das forças de gênero também dentro do ambiente especialista, para que isso se irradie para o grande público, o leigo, aquele que, basicamente, conhece os autores nacionais por meio das listas obrigatórias dos exames propedêuticos e de seleção. Lúcia Regina Vieira Romano (2009, p. 139) reitera que essa discussão a 
respeito das dramaturgas e dos espaços a serem conquistados pelas mulheres vem sendo negligenciada "em grande parte das universidades e cursos profissionalizantes de teatro", e que o estudo da prática teatral das mulheres "dialoga com inúmeras questões do fazer teatral na contemporaneidade, não se restringindo a um - fazer teatral de mulheres para mulheres". A respeito de Leilah Assumpção e do desvelar de dramaturgas, por exemplo, o debruçar demorado sobre sua obra ou sobre esse tema foi feito por mulheres, com um ou outro texto ocasional assinado por um homem.

Não é o caso de se construir supremacias, mas reparações históricas, construção de novos olhares e abordagens em que se quebre esse confinamento, esse gueto de mulheres que escrevem sobre mulheres para mulheres. Homens escrevem em nome de uma pretensa universalidade, já que estão no posto de controle e tudo que está milenarmente no controle acaba mascarado de condição natural, biológica, divina. A eles é possível esperar um leitor que não o confunda com sua obra, que se sinta tocado independentemente de seu gênero. Às mulheres, tudo parece pessoal em sua escrita, vasculham-se cantos para que se descubra a confusão biográfica entre autora e personagem, a mulher que só tem alcance para falar de suas experiências concretas e, portanto, menos criadora. O gênero grita na recepção do texto em um leitor preparado por um sistema que nebulou a diversidade dos autores e autoras e suas exponenciais multiplicidades na construção do universo fictício.

É simplista dizer que toda autora é feminista, sendo mais comum o que preconiza Maria Tereza Alario Trigueros em seu Arte y feminismo (2008, p. 32, tradução nossa): “Essa conexão entre a teoria e a prática artística feministas se faz patente no caso de algumas mulheres que, tornando-se mais conhecidas por uma das duas atividades, se desenvolverão também na outra". A noção de sujeito e suas representações é um elemento compartilhado pelas diversas direções tomadas pelo feminismo no séc. XX.

Nesse sentido, pode-se afirmar que todo ser humano já nasce dentro de uma causa. E uma mulher que busca romper espaços reservados a homens já se insere no contexto histórico de luta pelo direito das mulheres mesmo que ela não hasteie uma bandeira sobre isso. E se, por sua vez, os temas surjam de maneira enviesada em relação às expectativas previamente constituídas, se a mulher trouxer uma personagem feminina que corrói o signo da mulher construído pela 
autoria masculina, que refletia mais o parecer do homem sobre o ser mulher, a crítica arranjará um desvio para não ter que falar sobre isso. No caso de Maria Adelaide Amaral e Leilah Assumpção, o filtro escolhido foi confiná-las ao tema "classe média" ou, em uma concessão maior, caracterizá-las como filhas da onda de 1969, que assim trazem o tema da diversidade ao teatro. Mas não sem que a crítica atire antes algumas pitadas amargas, apontando que elas são também filhas do teatro que não preconizava mais a formação moral de uma sociedade justa, mas mantinha o foco no indivíduo - algo um tanto egoísta. Essa mesma estratégia foi utilizada para diminuir a grandiosidade de Jane Austen, por exemplo. Otto Maria Carpeaux, em seu massivo História da literatura ocidental, em uma raríssima e curta aparição do nome de uma autora, afirma que "na obra de Jane Austen estão ausentes a alta aristocracia e o povo [...], daí o protesto, sempre moderado, contra 'preconceitos e orgulhos' aristocráticos, e o protesto mordaz contra o gosto plebeu" (Carpeaux, 2011, p. 119). Matilde Serao, que assinava Neera em suas obras, é caracterizada como portadora de um "coração de uma mulher idealista e fraternal" (Carpeaux, 2011, p. 183). De Christina Rossetti, Carpeaux (2011, p. 183) afirma que "suas maiores poesias nunca foram escritas". Emily Dickinson ganha um pouco mais de espaço, mas, ainda assim, Carpeaux a classifica como "poesia para os poucos 'poet's poetry"' (p. 187); sobre Katherine Mansfield, afirma que a crítica, "por motivos de simpatia humana, tem prestado atenção algo exagerada" (p. 12); e Virginia Woolf é caracterizada como dona de "uma arte finíssima, requintada, um pouco de segunda mão" (p. 235). E assim segue.

Priscila Claro (2015) ressalta a importância da década de 1960 para a visibilidade das minorias. $O$ fato de a censura ter impedido o teatro de denúncias sociais e de conflitos de classe explícitos acabou gerando, involuntariamente, um espaço em que outras possibilidades de representar o mundo pudessem se desenvolver. Entre elas, o teatro escrito e dirigido por mulheres, que começaram a se ver no "comando do olhar do mundo sobre seus espetáculos" (Claro, 2015, p. 29). Nesse sentido, as mulheres puderam representar a si mesmas sem seguir os padrões estabelecidos pelas autorias masculinas, os outros, o mundo, o ser humano; sem serem consideradas inadequadas para tal tarefa, estabeleceram-se como sujeitos criadores e a quem se permite assinar as próprias obras e ter o comando sobre sua produção. Heloísa Pontes (2013, p. 14) corrobora essa ideia ao afirmar que "As mulheres 
entraram na cena escrita não mais de forma isolada e esporádica, mas como 'um conjunto de nomes de autores que, por sua vez, integra um grupo mais amplo de dramaturgos estreantes, o qual veio a ser conhecido como o da nova dramaturgia'". As mulheres, antes conhecidas apenas como atrizes, puderam invadir como autoras e diretoras os nichos ocupados por homens no teatro e confrontar a divisão de classes em que elas eram sempre o segundo escalão.

Sandra Pellegrini (2007, p. 289-290) coloca a importância de Leilah Assumpção nesse cenário em que as escritas da autora "são significativas, pois se inserem no âmbito das tentativas de problematizar as práticas femininas expressas numa modalidade teatral não predisposta à resistência explicitamente política, nem centrada na figura do proletariado". Essa conjuntura será retomada nas peças da dramaturga que colocam em discussão o movimento de esquerda e sua centralização, que impedia participação das mulheres nas esferas mais altas de decisões, bem como suas fragilidades, como nas peças Boca molhada de paixão calada (1984), Jorginho: o Machão (1970), Kuka: o segredo da alma de ouro (1980) e Vejo um vulto na janela, me acudam que sou donzela (1964). ${ }^{4}$

A expressão das minorias é um dos movimentos saudáveis que as tomadas dos espaços de representação estabeleceram. Há, ainda por acontecer, a expectativa de que as minorias ocupem os espaços hegemônicos, saiam dos subterrâneos e "espaços alternativos" e dos "grupos de estudo" e ganhem as ruas, os espaços do mainstream, não só dos ambientes virtuais, mas das grandes mídias populares. Espera-se que as representações não permaneçam segregadas, restritas aos grupos que representam, mas que atinjam o mesmo que qualquer livro de autor branco francês consegue no Brasil: ser visto com o devido tratamento artístico ao humano, sem ser recebido como algo que não fosse possível de ser traduzido tão plenamente a todos os leitores. Demandará séculos de resistência para que o default de nosso cérebro não seja a visualização de personagens brancos, com homens protagonistas e mulheres coadjuvantes, mas de todas as cores e representatividades. Para isso, é preciso romper com as ideologias que geram esse "espectador resistente" que lê "o espetáculo por meio dos estereótipos e não se

\footnotetext{
${ }^{4}$ Dada a dificuldade de se conseguir os textos de todas as suas peças, foi utilizada como fonte das citações, para a análise desenvolvida neste artigo, a coletânea Onze peças de Leilah Assumpção (2010), coligida pela própria autora e que abarca o período de 1964 a 2008.
} 
permitindo manipulação pelo texto do espetáculo e pelo texto cultural formulados pela cena" (Romano, 2009, p. 260).

Leilah Assumpção traz essa complexidade para suas peças, resgata essa discussão do deserto arenoso de apenas ver a mulher e não todas nas diversas peças que a conectam ao humano. Falar de qualquer ser humano é explorar o humano, mas, no caso das autoras, a resistência dos leitores e espectadores homens em se deixar levar pela história, em permitir que ela aconteça sem reservas, acaba particularizando em demasia as ações engendradas pelas personagens como algo aplicável apenas às mulheres. $O$ receptor, imerso em condicionamentos ideológicos em que o ser mulher não é traduzível a todos como o ser homem, ou seja, a plateia, alimentada por uma sociedade sufocantemente machista, enrijece-se e passa a defender, consciente ou inconscientemente, os poderes já estabelecidos. A autora discute sobre isso e coloca homens e mulheres se debatendo em relacionamentos que não evoluem pelo total desconhecimento das movimentações internas um do outro. $\mathrm{O}$ sexo não promove intimidade, o casamento não gera intimidade, apenas a coragem de deixar as máscaras caírem.

\section{Chama a Mariazinha e esquece as outras}

É sintomático que a peça de maior repercussão de Leilah Assumpção - tanto no pouco espaço da historiografia do teatro quanto na crítica teatral - tenha sido Fala baixo senão eu grito (1969). A peça apresenta uma mulher cristalizada pelas convenções sociais e jogada no limbo por elas, já que não alcançou o que se esperava dela: o casamento, os filhos, os cuidados com o lar e a família. Mariazinha é a chamada solteirona, cheia de laços, manias, apego à repetição dos dias, que sofre de uma inquietação que não sabe verbalizar ou identificar. Um sujeito sem nome, simplesmente chamado de Homem, invade seu quarto e as ações ganham algo de improvável e loucura enquanto ele a estimula a vivenciar situações fictícias e a quebrar o seu quarto cheio de símbolos de convenções e aprisionamentos.

Essa situação insólita não impede que Mariazinha seja ofendida pelo Homem ou que possa guiar as cenas que inventavam de acordo com seus próprios desejos, sempre interrompida e julgada por ele, que dizia desejar libertá-la dessa vida anestesiada. Seu nome é comum, no diminutivo, eivado das concepções ocidentais da mulher virginal e comum, porto de 
passagem para o que realmente importa e que não é ela. Talvez o fato de Mariazinha ter sido tão marcante na percepção da crítica venha de algo que não pertence ao critério estético ou artístico, mas ao fato de que nela está apenas um embrião do que viriam a ser as personagens femininas de Leilah Assumpção, explicitamente fincando seus pés em posições que antes lhes eram negadas, explicitamente falando de seus desejos de mulheres modernas e que extrapolam as paredes da cozinha e da existência do pai, do marido, dos filhos. Mariazinha não aceita a possibilidade de mudança ao final da peça, não se atreve a quebrar as convenções, ela volta para o lugar que lhe designaram. Para o ano de 1969, em que as minorias encontraram seu espaço de voz e se revoltaram contra o esquema de denúncia proletária preconizado pelos "donos" do que deveria ser o teatro em tempos de ditadura, essa reflexão era "permitida" até pelos machistas de esquerda. Não há uma ruptura efetiva de padrões que afrontassem o machismo, que não é privilégio de um único partido político ou vertente ideológica. Essa reflexão atravessa várias peças da autora, como se pode vislumbrar a seguir.

CECÍlIA: No fundo é idêntica à turma da Carminha, os "fisgadores" do outro lado, da de-mo-crrá-ti-ca direita fedorenta. Mas eu acho você menos pior, só que não nasci para bucha de canhão não. Ou tu me bota lá em cima do teu Partido Comunista, sabendo de tooooodos os mistérios e suspenses, ou nada feito. É chato ser sabidona inútil, mas inocente é que não vou ser não (Vejo um vulto na janela, me acudam que sou donzela, 2010, p. 46).

ANTÔNIO: Eu não posso fazer uma peça confusa, individualista, intimista, psicológica, bicha, alienada e mística. É contra os meus princípios, eu sou um artista engajado, eu sou um intelectual marxista! (Boca molhada de paixão calada, Assumpção, 2010, p. 379).

Leilah Assumpção coloca, recorrentemente, a questão de que a condição da mulher não é respeitada nem pelos ditadores, nem pelos rebeldes. A sociedade que pretendem libertar ou constituir não se revisa em seus paradigmas profundos, e não pretendem subverter hierarquias ou relações de poder; a luta de classes ainda era, em raso resumo, a luta por homens para se colocarem na posição controladora de outros também homens. E essas provocações, ainda hoje, provocam mal-estar.

Duas ações denunciadas como machistas - a de retirar a autoridade do discurso da mulher e de silenciá-la - são praticadas constantemente pelo Homem contra Mariazinha. Na discussão da cor de um enfeite do quarto, 
ele teima em dizer que ela não vê a cor certa, um detalhe que deveria ser óbvio, mas nem a essa certeza ele permite que ela tenha acesso.

MARIAZINHA: Eu não escuto e não entendo! Não me deixa ver a cor que eu quero! Eu não escuto! Eu não escuto e não entendo e não tenho a obrigação de entender.

HOMEM: [...] Cala a boca, cala a boca, cala a boca, cala a boca, a boooooooooooooca!!! (pausa) Isso. Cala a boca. E eu fico berrando! Berro quanto eu quiser! Berro o que eu quiser!!!... (Fala baixo senão eu grito, Assumpção, 2010, p.113).

A indefinição do que aquele homem realmente deseja, espera dela, a deixa desnorteada enquanto tenta acompanhá-lo. Ele é o dono da ação, é quem a movimenta, quem inventa os jogos, quem a desestabiliza em seu mimetismo com o criado-mudo, silencioso, com gavetas cheias de miudezas. Durante esse jogo, ela expressa seu desejo de ser vista potencializado à esfera de estrela de cinema, fala do sonho negado de ser artista e deseja devolver, em alta voltagem, o abandono a que foi relegada pelo mundo dos homens, efabulando a morte de dezenas deles, que se matariam pelo amor que ela não corresponderia. São nesses pequenos momentos que Mariazinha evidencia quem gostaria de ter sido, em um extremo contraste com quem ela foi forçada a ser. As aspirações não morrem, nem com a máquina social girando sem parar para que isso aconteça; ficam soterradas, transformadas em cacoete ou algo visto como doença.

Em seu sonho de liberdade, Mariazinha só não consegue traduzir o que isso seria para ela. Comprar muitos vestidos, não se ocupar com a sobrevivência e a segurança de terminar de pagar a quitinete, a certeza do teto frente às pequenas injustiças de seu dia a dia. A recorrência das personagens de Leilah de quase nunca faltarem ao trabalho está exposta.

A farsa de que esse homem queria libertá-la é denunciada assim que ele apresenta as pressões sociais que também se depositam sobre ombros masculinos: "Pensa que dinheiro dá em árvore? Aí, garanhão! Parece mulher da vida! O que vão pensar de mim? O que vão pensar de mim? Vencer na vida. Vencer na vida. Vencer na vida. Vencer na vida" (Assumpção, 2010, p. 116). Ele deseja ser ouvido, entender-se, superar essas pressões, mas nega isso a ela, chama-a de "bagulho", a diminui, a humilha, e as relações cristalizadas entre homem e mulher se evidenciam. 
MARIAZINHA: Minta! Eu quero uma mentira! Eu acredito! Juro por Deus que acredito! Eu preciso de uma mentira em que eu possa acreditar! [...]

HOMEM: Casar! Ah! Ah! Ah! Ah! Ah! Ah! Ah, nem mentindo dá, bagulho! "Bagulho independente". Pra trepar pode servir sim, mas ninguém quer uma puta pra mãe dos próprios filhos! De independente chega eu, o que é que há? Afinal o papai aqui nasceu machão pra quê? (Fala baixo senão eu grito, Assumpção, 2010, p. 150)

Ela apresenta ser entendedora, sim, dos jogos sociais, e tem uma íntima percepção da injustiça dos relacionamentos, mas, ainda assim, ser enganada a livra da culpa de ter cedido a seu impulso. Ser enganada é algo mais aceitável que expressar sua vontade. E ele, no discurso marcado pela histeria das exclamações e das risadas reitera um dos argumentos mais clichês da misoginia, a dicotomia entre esposa e puta, entre mulher que tem filhos e mulher que tem prazer, entre mulher que merece a condescendência masculina e a que não, as duas usadas por ele.

Mariazinha namora com a ideia de suicídio, algo para o que a sociedade já a estava encaminhando, pelo seu apagamento, pela inutilidade da existência de uma mulher incompetente, por não ter conseguido um marido e, assim, não ter procriado. $O$ homem, apresentando sua angústia, diz que nunca pensou e nem pensa em se matar. Ela insiste até irritá-lo, questionando se ele pensaria algum dia ao menos. A disparidade da relação só ganha cores mais fortes. A inadequação ao mundo era um conflito para ele e mortal para ela, enterrada viva na repartição e no seu quarto. Até que ela traduza perfeitamente sua condição: "Ah... Eu pensava que eles passavam o dia inteiro pensando em mim, e ao mesmo tempo não sabiam que eu existia, entende?" (Assumpção, 2010, p. 138).

Fala baixo senão eu grito é uma peça forte e produtiva, assim como as outras que a precederam e que se seguiram. Mas a impermeabilidade da plateia e da crítica para entender os sentidos mais profundos da obra, que passavam pela libertação feminina, fez com que ela, por não ser explícita nessa discussão, fosse eleita para nublar a assertividade das demais.

\section{O ying e o yang: entre a valsa e o confronto}

Relacionamentos amorosos parecem povoar o imaginário como chave para a plenitude do existir da mulher, que é medida por sua 
capacidade de atrair e "segurar" o homem ao seu lado e receber o troféu de mãe dos filhos dele. Por mais medieval que isso possa parecer, as receitas para esse "sucesso" estampam capas de revistas para o público feminino, cursos de danças eróticas para seduzir o companheiro, a perversão de filosofias milenares que encapsula o "sagrado feminino" vendido em formato de cursos, acompanhamentos, vestuários e rituais pagos. É tanta energia dispendida nesse processo de captura e manutenção do homem que sobra pouco espaço para que as mulheres repensem e movimentem suas rotinas e desejos em direções diferentes.

Falar de relacionamentos faz parte da emancipação feminina na medida em que eles sejam medidos, avaliados, desmontados, descartados, reconfigurados, e em que os paradigmas sejam realmente e profundamente modificados. E mais, a dramaturga desvenda a complexidade das relações entre os gêneros em que não cabem distinções simplistas entre homens maus, mulheres boas, homens machistas e mulheres feministas. Como aponta uma análise rápida feita por Sábato Magaldi (2015, p. 139): “assiste-se, em Fala baixo, a uma autêntica explosão do universo feminino. A intuição da autora é tão impressionante, porém que se vê também o desnudamento do mundo masculino, numa sondagem que abole todos os sistemas convencionais". Esse eixo atravessa toda a obra de Leilah Assumpção, e mais fortemente ainda em peças que não receberam tanta atenção quanto Fala baixo senão eu grito (1969).

A figura masculina é delineada por seus atritos com a feminina, a construção da identidade de um está fortemente vincada e eivada pela do outro. Nos primeiros momentos das peças, parece que o homem está no controle, que ele coordena a vida de todos, e a mulher aceita com tristeza e resignação o papel que lhe é destinado. Mas logo as máscaras caem e não há um personagem seguro de si e de seu lugar no mundo. Em Roda cor de roda (1975), há um grito que não aceita o feminismo da primeira água; também em O momento de Mariana (1999), tem-se a igualdade de papéis que, sem a reflexão necessária, só mudaria o chicote de mão. Leilah pretende fazer ruir a ideia do chicote. Em Roda cor de roda, Amélia, esposa prendada de Orlando, tenta suportar as traições do marido enquanto alinhava o bem-estar material de sua família, botões pregados, casa limpa, ela mesma vestida de rosa e cheirosa, organizando o orçamento para a Caloi do filho e o apartamento em Bertioga. Todo um ritual que voará feito cinzas 
apresentando não os conflitos da classe média, mas do ser humano esvaziado da compreensão de si mesmo e sufocado pelas coisas, pelos desejos impostos por convenções e longe de serem genuínos. Amélia liga para a amante Marieta, que vai visitá-la, momento em que a falsa aceitação de Amélia se esvai em uma sucessão de frases marcadas por exclamações e alongamentos de vogais, na clara intenção da autora de deixar explícita a revolta e o descontrole da esposa. Marieta e Orlando tentam subjugar Amélia por uma conversa non sense em que há a pantomima de intelectualidade e racionalidade. Para se vingar, Amélia vira puta. Os papéis rodopiam e se invertem.

O humor sempre esperto da dramaturga se faz presente a todo momento, mesmo nos momentos de maior tensão, por exemplo, ao mandar Orlando, com voz doce, tomar no $\mathrm{cu}$, e os lugares estão marcados. O dominador tem uma razão biológica para trair, é um bom cidadão, pagador de contas, cuida financeiramente da família e isso abona o abandono afetivo contra a esposa e os filhos. A indiferença é sempre a maior das agressões e o diálogo vazio que torna a mulher invisível, construído pela função fática de quem só finge ouvir algo, vai anulando a oprimida, retirando-lhe a voz, a autoestima, e tenta enfiarlhe por todos os poros a ideia de que "é assim mesmo". As inconformadas sofrem mais, não conseguem mentir até acreditar.

AMÉLIA: Espero monogamicamente esse homem maravilhoso, que, como pai e cidadão, é um homem exemplar. Todo mundo diz que o Orlando é um cidadão exemplar. E essa Marieta até que foi simpática no telefone. Eu é que exagerei um pouco. Afinal, tem tanta amante que pede até casaco de pele! (p. 220)

ORLANDO: Amelinha, meu amor... Todo homem pula a cerca, mas esposa é uma só...

AMÉLIA: (terna) Orlando...

ORLANDO: Sim?

AMÉLIA: (delicadamente) Vai tomar no cu... (Roda cor de roda, Assumpção, 2010, p. 228).

Amélia ter se tornado uma prostituta faz dela uma imagem viva do medo e atração do homem por perda de propriedade e satisfação carnal. Todavia, não melhora a posição da mulher, que continua a ser objeto de uso e consumo masculinos. É uma vingança que afeta o direito de posse, mas não liberta o corpo da mulher de servir. Ela assume o pensamento pragmático e capitalista atribuído ao homem pela sociedade. 
Comercializa-se com eficiência e ganha mais dinheiro que seu marido no trabalho de que ele tanto se orgulhava. A prostituta é a provedora. Seu sexo é uma empresa. Ela agora é quem vai transformar Orlando em sua esposa e devolver a ele cada ação que antes havia perpetrado contra ela. Fá-lo-á invisível, dependente, inseguro, necessitado de agradá-la. Mudou quem conduz, mas a dança continua a mesma. A ironia está em colocar um homem para repetir o mesmo discurso proferido por Amélia no começo da peça. Na boca dela, foi o sofrimento de uma esposa honesta. Na dele, uma piada que incomoda, um desajuste total de lugares.

Esse giro completo dos polos de poder, pela escrita de Leilah, extrapola o fato de apresentar as dificuldades da mulher em uma sociedade machista, vai mais fundo, toca na dificuldade humana de construir relacionamentos que não se assentem no poder sobre o outro, sobre quem ele é e o que faz, como Orlando, que assume até a posição de Amélia no sofá: "Assim ela me abandona! (olha no espelho vaidoso) Tenho que me cuidar! A melhor coisa para afastar a esposa é ela chegar do trabalho e encontrar o marido com roupa suja e despenteado. Isso destrói o casamento" (Roda cor de roda, Assumpção, 2010, p. 245).

A culminância desse processo de vingança instaurado por Amélia está em subjugar Marieta, a vagabunda infame destruidora de lares, conquistá-la fazendo-a se sentir especial, retirar Orlando de casa e colocá-la em sua posição inicial de dona de casa. Todos os três passam por esse lugar, o do sofá da espera não correspondida, da invisibilidade, do abandono afetivo. A esposa é levada a ele, e depois ela leva o marido adúltero e a amante a essa mesma posição. Nesse lugar do machista, Amélia abandona inclusive os filhos, retirando de si qualquer acesso maternal ou necessidade de ofertar algum afeto; endurece e trata os filhos como um problema a ser passado adiante, no caso, para Marieta, que agora é quem vai viver às voltas com a urticária do menino. Essa urticária é a ilustração mórbida da superação do nojo das feridas requisitada às mulheres e desvalorizada nos homens. Tocar em fezes, limpar vômitos, passar pomadas em feridas, não são ações que condigam com a esfera masculina, isso os tornaria menos machos. Essa abnegação é coisa de quem já foi biologicamente predestinado a isso as mulheres. Amélia desmente isso, mas Orlando não assume a paternidade e suas demandas afetivas e de cuidados em nenhum momento. É como se as crianças fossem balões lançados ao ar e quem as socorresse sempre fosse uma mão feminina. 
MARIETA: (chorando) Desculpa, Orlando... desculpa. Eu não quero magoar ninguém... Eu tentei ignorar, mas é tão mais forte que eu. Ela foi tão boa comigo. A gente se via na rua. Escondido, a gente se via. Ela foi tão compreensiva...

MARIETA: As tuas crianças! As tuas! E o coitado do Zezinho morrendo de tanta urticária! Eu aqui economizando, Amélia, pra você gastar em farra, sua machista ordinária! Você não passa de um prostituto, puto, Orlando! (Roda cor de roda, Assumpção, 2010, p. 266).

Marieta, aquela que foi coadjuvante de um casamento doentio e não a protagonista, apresenta uma visão da autora ainda mais contundente: a de que a amante não é o elemento diluidor do casamento, mas o próprio casamento entre pessoas que não interagem verdadeiramente, que não se conhecem nas ambições e além das máscaras recebidas pelas convenções sociais. Ninguém quer chegar perto demais do outro. E o sexo não é um elemento integrador, mas desintegrador. A ex-amante tem a lucidez de enxergar que Amélia e Orlando são a mesma coisa, não interessa se foi homem ou mulher o comandante do outro, não é saudável para ninguém o homem dono da mulher e tampouco a mulher dona do homem. Daí, o rosa envergado por Amélia e depois por Orlando ser negado. Marieta quer colocá-los para girar, não como fizeram, um giro de salão com a mesma música. Ela quer fazê-los girar vertiginosamente, até as cores se confundirem, até a noção de espaço se perder, até tudo virar um movimento de indistinção entre os gêneros, inclusive da mulher explorada pela mulher.

MARIETA: Vocês pensam que mudaram, e só trocaram os papéis.

Dentro do mesmo cenário, mesmo espaço e texto, mesma ideia e mesmo tempo, só movimento e tensão, correria e gargalhada, apenas badalação, P-I-A-D-A! P-I-A-D-A! E aqui dentro não aconteceu nada. Não houve transformação! (Roda cor de roda, Assumpção, 2010, p. 276)

Em Lua nua (1987), o tom diminui um pouco e vemos novamente o ambiente preferido por Leilah, a sala, onde as convenções sociais todas ficam bem representadas até que as visitas saiam. A crise do casal chega pelas mãos do homem que se sente mais importante e da mulher cansada da maternidade, que é inclusive um dos pontos mais problemáticos para as mulheres do universo de Leilah, que representa bem o espírito da época em que escreveu essas peças, retomado em $O$ momento de Mariana (1999), por exemplo: “Eu nasci tendo que obedecer. Primeiro tinha que 
obedecer à minha mãe ao meu pai. Depois ao noivo. Aí ao marido. E agora tenho que obedecer aos filhos!" (2010, p. 515). Mary Del Priore, em História do amor no Brasil (2012), apresenta que o conceito de paternidade mais amorosa, responsável, a ideia de contracepção e planejamento familiar estavam ganhando força entre as décadas de 1960 e 1970 no Brasil, e que muitos casais da elite, para não depredarem seus patrimônios simbólicos e materiais de famílias bem-sucedidas e sólidas, preferiam o caos extraconjugal à separação (Priore, 2012, p. 147 e 150).

Dessa forma, os homens estavam sendo chamados a revisar seus papéis dentro das esferas familiares. O grande atrito nasce da "permissão" à mulher para trabalhar fora, desde que continue com todas as outras responsabilidades, do cuidado do lar, dos filhos, do marido e do cuidado de si para agradar ao marido. $\mathrm{O}$ corpo feminino ainda é um produto na vitrine, recebendo seu valor mediante a capacidade de agradar mais ou menos aos homens. $\mathrm{O}$ homem ainda se apega aos valores tradicionais por não saber exatamente quais são os novos. Em Lua nua (1987), Lúcio é extremamente agressivo com Dulce, xinga seu corpo pós-gestação, ofende-a constantemente e age como se o trabalho dela fosse um passatempo.

LÚCIO: Só que o que eu acho, Sílvia, é exatamente isso. Uma planta é só uma planta, mais nada. E o mundo, minha amiga, é dos fortes; os mais fortes criam anticorpos e ficam. $\mathrm{O}$ resto... (assopra) vira fóssil. Mas acho também que não há força que resista, nem samambaias, nem a Amazônia inteira, à infinita ineficiência sua para administrar isso a que damos o nome de lar (Lua nua, Assumpção, 2010, p. 413).

Essa mesma samambaia será a chave de revelação quando descobre que foi ele mesmo que a matou ao confundir alvejante com vitaminas, em seu claro desconhecimento das dinâmicas domésticas. Nesse ponto, ele questiona o papel que desempenhou dentro da família, sua angústia em cumprir com as expectativas sociais de ser um homem competitivo, bem-sucedido, provedor. Não se conhece direito ao ponto de não saber se deseja mesmo a promoção e, ao mesmo tempo, aturdido pelas contas cada vez mais altas de um país em crise. Olha para a mulher descobrindo novamente sua presença. Ela havia colocado em forma objetiva todas as agonias:

SÍLVIA Ah! Não foi meu seio que perdeu o atrevimento, não, fui eu inteira, eu vi no espelho, é questão de postura, eu estou arcada, 
como se carregasse o mundo nas minhas costas! Você dorme de noite e tem fim de semana, a Dulce tem também fim de semana, eu nunca! Nem férias! Eu não sou Deus mes-mo! Eu e Ele fizemos o mundo juntos sim, em seis dias. Mas Ele, o senhor, no sétimo descansou! (Lua nua, Assumpção, 2010, p. 439).

As personagens femininas de Leilah Assumpção estão marcadas, em sua maioria, pelo cansaço, pela exigência da maternidade e por um mercado de trabalho que não se flexibiliza às mulheres com filhos. Querem alcançar o sucesso profissional, mas se angustiam tanto quanto os homens ao debaterem o que seria esse sucesso e se essa medida de poder e dinheiro corresponde às suas expectativas. Em Boca molhada de paixão calada (1984), Antônio e Camila também discutem essas tarefas domésticas e é ela quem cede e fica em casa abandonando um compromisso seu para ficar com as crianças enquanto o marido cumpre o dele. Contudo, a mulher não está só nesse vórtice e, por conseguinte, não pode reformular a si mesma sem que isso atravesse e perturbe a realidade masculina. Quando se nega o direito a uma pessoa, outra recebe o dobro. De repente, o homem que antes tinha a supremacia sobre tudo e todas, agora, vê seus territórios diminuírem. A luta fica ainda mais encarniçada e o holofote recairá sobre as cobranças que ele agora deverá atender.

O homem, no universo de Leilah Assumpção, passa pelo machista preconceituoso e agressivo, como Otávio, em Jorginho, o machão (1970), e pelo conflito embrionário, como Homem, em Fala baixo senão eu grito (1969), Jorge, em Ilustríssimo filho da mãe (2008), Mariano, em Intimidade indecente (2001), Lúcio, em Lua Nua (1987) e Roberto, em O momento de Mariana (1999), mas não chega ao nível de superar o antigo e construir algo verdadeiramente novo. Os homens repensam suas carreiras, as expectativas depositadas sobre eles, as expectativas que possuem sobre as mulheres, mas nada é algo realmente transformador, as peças acabam no momento em que se inicia essa tomada de consciência, como em Boca molhada de paixão calada: "Nós já nos amamos sim, Camila. O problema sempre foi... não sei... talvez você tenha razão sim, sempre me veio uma coisa forte de dentro me segurando e dizendo não... O medo de concordar e não ser mais eu" (Assumpção, 2010, p. 393).

Encontramos esses homens que só conheciam as próprias presunções cristalizadas sobre suas mulheres e sobre eles mesmos e agiam na antecipação de ações legadas por pressupostos que não 
foram questionados. Jorge, em Ilustríssimo filho da mãe (2008), queria tocar piano e não ser um executivo. Sentia-se diminuído pelo fato de a mulher ser muito mais bem-sucedida que ele, e seu lugar confortável seria numa posição em que não houvesse parâmetros nos quais ele pudesse ser comparado a ela. A figura masculina sobe no pêndulo que a leva para longe do capitalista bem-sucedido. A feminina surge na compreensão, na capacidade de dialogar com essa pessoa que vê surgir. Camila e Antônio, de Boca molhada de paixão calada (1984), em seus jogos eróticos na busca de uma "emoção maior", só conseguem incorporar estereótipos e se distanciar ainda mais da performance sexual idealizada. $O$ encontro só acontece realmente quando se apresentam frágeis, sem escudos, quando assumem a necessidade um do outro e o medo de perderem a si mesmos nessa entrega sem reservas. Esse é o momento do encontro sincero entre um homem e uma mulher, só repetido em Kuka - O segredo da alma de ouro (1980), que o exponencializa e faz o homem e a mulher se fundirem em uma escultura, eternizando um momento de conjunção e comunhão.

$\mathrm{O}$ último rincão do macho, sua heterossexualidade a toda prova, também é colocado na berlinda quando Jorge confessa ter tido sua primeira experiência sexual com Caio, e Antônio admite ter experimentado uma relação homossexual. Homens que se permitiram experimentar outras formas de relacionar-se com outros seres humanos. É essa tentativa, sempre frustrada, de se equilibrar os gêneros e não confundi-los que está sempre atravessando as peças de Leilah Assumpção.

O homem que não estiver gerando um questionamento produtivo sobre si mesmo pode desembocar em uma criatura inútil, incapaz de estabelecer suas próprias fronteiras e realizações. Jorginho, de Jorginho, $o$ machão (1970) é um megalomaníaco incapaz de assumir qualquer mudança ou responsabilidade. Questiona o pai capitalista e é tão machista quanto ele; diz não precisar de ninguém e, ao mesmo tempo, é inerte. Um homem interrompido, que não evolui a partir dos questionamentos que faz e que se esvaziam: "Respeita o pau, velho maluco, isto que é pau, o resto é palito! O maior pau do Brasil! O maior pau da América Latina! O maior pau deste hemisfério! O maior do planeta Terra! O maior do sistema solar! O maior! O maior! O maior pau da Rua do Cemitério!!!!!!!!!" (Assumpção, 2010, p. 176).

O pai de Mariana, em O momento de Mariana Martins (1999), é uma voz dissonante desse universo das figuras masculinas. Ele deseja a 
emancipação da filha, que trabalhe e seja feliz, independentemente de filhos e marido - "Quê... Pra ficar feito uma barata, enrolada nos lençóis e panos de cozinha? Trabalhando ela ficou mais jovem, mudou até a postura, parece uma garça!" (Assumpção, 2010, p. 511) - e oferece a ela a referência de deusas, Celene, a moradora da lua, que se procura olhando para o alto.

Esse movimento de translação de discursos é um recurso constantemente utilizado por Leilah Assumpção, em que o discurso machista e o feminista não estão confinados à boca do homem ou da mulher, um dos muitos recursos eficazes de que ela lança mão para não cair no panfletário e na perda do ritmo cênico em favor de manifestos. Aproxima-se mais da vida, em que as pessoas não são planas. $\mathrm{O}$ pai, sendo essa variável libertadora, transforma-se em um referencial poderoso para Mariana, que pode tanto encolhê-la ao contato masculino, quanto fortalecê-la, apesar dele. Nessa mesma peça, outro traço da figura masculina chega com todo o humor de Leilah. O clichê do homem de meia idade tentando afirmar sua virilidade com meninas mais novas, que também é muito bem explorado em $O$ momento de Mariana (1999) e Intimidade indecente (2001).

MARIANA: Pra que ter vindo pra são Paulo, pra que tudo o que fiz, tanto esforço, malabarismo, tanta correria, aperta daqui, repuxa dali, tantos cuidados pra nada, NADA! Pra agora o Roberto me trocar por duas gêmeas loiras univitelinas de 20 anos (O momento de Mariana, Assumpção, 2010, p. 504).

MARIANO: Meu pau! A que ponto a gente chega... Ter que fingir para mim mesmo que não sei que ela está aqui só por interesse... $\mathrm{O}$ relógio era de estimação. Acho que é por isso que não gosto mais de me olhar no espelho (Intimidade indecente, Assumpção, 2010, p. 562).

Os homens estão em conflito e as mulheres também. Questionam-se a respeito de seu próprio corpo e dos "sacrifícios" que fazem para prolongar sua juventude, das medidas sociais cruéis contra as mulheres que envelhecem, mas com uma diferença: as mulheres já estão a tatear novas possibilidades de existir e de possuir esse corpo alienígena que portam, mas não possuem. Os maridos e ex-maridos ainda estão presos ao ideal de se provarem pela rigidez do pênis, pela capacidade de conquistarem um corpo de mulher jovem. A virilidade vai sendo substituída pelas vantagens econômicas que podem oferecer e, por um breve momento, parece que o jogo vira e eles é que passam a estar "nas 
mãos" das mulheres, que os comandam nesse mercado das ilusões das sexualidades potentes. Essa temática é tratada com muito bom humor por Leilah, que prefere se aproximar dessa discussão pelo riso, ainda a melhor arma para se desarmar uma plateia cheia de conceitos vulcanizados a respeito de alguns temas-tabu.

Há o outro lado do muro também, agora, as mulheres também desejam uma satisfação sexual ainda hibridizada com senso comum, convenção, regras externas a si mesmas e o real desejo. Querem se satisfazer sexualmente, mas a mensagem que chega aos ouvidos masculinos perverte todos os papeis rigidamente construídos, em que cada um sabia exatamente quais movimentos lhes eram permitidos. Até desejam ser o performer sexual idealizado pelas mulheres, mas soa como dois cegos tentando encontrar um apito em uma sala escura. A revolução sexual só acontecerá mesmo quando cada ser humano sondar-se com menos ruídos externos, e isso passa pela exploração do próprio corpo e do jogo compartilhado de exploração com o outro, sem a famosa meta corporativa que contaminou todas as esferas de existência do homem moderno. Bauman (2005, p. 6) constrói essa ideia de que identidade e pertencimento são dinâmicos e em constante mutação. Observar tais aspectos pela perspectiva da ação e da decisão é crucial para que se estabeleçam no indivíduo, que não deve assumi-los como "destino". Os papéis cristalizados devem ser derretidos e observados como lugar de escrita e não de escrito, e que se apegar a algo permanente como elemento norteador da convivência humana é contradizer a condição de mortais e é portal para desigualdades e frustração.

\section{O que vão pensar de mim no meu dia branco?}

O dia branco, traduzido pelo Homem de Fala baixo senão eu grito (1969), é o dia um, em que não se cumprem obrigações com o trabalho, com a família, com ninguém, um dia para se fazer algo que não está previsto na rotina. Qual seria o dia branco para as mulheres dentro de uma sociedade toda construída e moldada para que sejam inferiores e obrigatoriamente conduzidas para atender necessidades e desejos alheios a elas? Como ficariam em relação ao próprio corpo, à maternidade, ao trabalho, aos amigos, à história, ao outro? Essa é uma construção infindável, mas que vale como ponto de partida para se 
questionar quão longe o ser humano pode ir para além das pressões e pulsões sociais, ideológicas, históricas. E será possível ganhar distância? Provavelmente, esse distanciamento histórico não é possível, mas sua crítica para a constituição de novos paradigmas, padrões e referências, sim. Modificar estruturas sem abandonar o castelo.

Leilah Assumpção coloca esse questionamento, aponta onde estão os focos de tortura feminina, masculina, humana, mas seus personagens têm a impotência de não responderem perguntas para além deles mesmos, de como seriam a nova mulher e o novo homem. Estão anestesiados e desgastados pela vida e suas cobranças, querem quebrar condicionamentos, buscar alternativas, mas ora caem em uma espécie de autismo que os distancia da alteridade, do outro, e os colocam a girar em torno de si mesmos, ora fincam-se no conforto de seguir regras claras, prontas, fixas, anteriores a eles mesmos e, portanto, fora de suas responsabilidades, apenas seguem sem dar voz aos conflitos das muitas vozes silenciadas dentro de si.

O grande erro das ondas de reforma social que acontecem de tempos em tempos é pensar que todos estarão, de forma homogênea, prontos para elas, que cada mulher quer mudar o modelo de vida em que está. Como bem acusa a dramaturga aos movimentos de esquerda de repetirem o mesmo erro que o sistema autocrático, o uso de pessoas sem se preocuparem com elas, os "inocentes úteis", as escadas que servirão para o "bem maior" independentemente de desejarem ou não fazer parte. De certa forma, sempre haverá um grupo querendo dizer aos outros o que é melhor para todos, e essa é a angústia que navega em Vejo um vulto na janela, me acudam que eu sou donzela (1964), em que cada uma das mulheres do pensionato possui uma história que a diferencia das outras e todas são unidas pela exploração masculina de alguma forma.

Nas peças de Leilah Assumpção, não há uma única mulher. Há muitas mulheres diferentes entre si, a que se endurece e se transforma em um autômato repetidor do discurso machista, disposta a agir como verduga de outras mulheres; a que constrói uma fala feminista, mas continua explorando outra mulher; a que obedece às regras e enlouquece o mínimo possível para não ser descartada de vez pela sociedade; a que percebe os papéis apenas trocando de mãos e tenta modificá-los; as que entraram no jogo social e tentam se adaptar a ele, mas sofrem com o medo; as que repetem o autômato agora com discurso feminista, mas que continuam a desejar serem aceitas pela sociedade. 
Jorginho, o machão (1970) traz o embate entre a mãe superprotetora, a noiva (aparentemente imbecilizada, mas apenas esperta para alcançar seu lugar padrão na sociedade) e a namorada da outra cidade. É totalmente inerte e impotente diante das três e de seu pai. Madalena, a mãe, tem muito orgulho do casamento vantajoso que sua filha conseguiu; não toca no nome da nora do segundo filho; e o caçula, tratado no diminutivo, é alvo de sua vingança contra o marido dominador e agressivo, amolecendo-lhe a vontade, utilizando-o como a única trincheira em que uma mulher poderia confrontar o marido, no cuidado do filho. Por outro lado, mantendo esse filho em suas saias, assumiria, contraditoriamente, a figura controladora de outra mulher, no caso, a futura esposa de seu protegido. Não é, dessa maneira, uma consciência de classe e de gênero, mas o compromisso paradoxal entre submeter-se e desejar ter o poder. A esposa exemplar recebe notícias do mundo pelo marido, vê a violência, mas prefere fingir que se engana, que consegue se desvencilhar da brutalidade humana mesmo presenciando-a a colheradas em seu cotidiano.

A perspectiva é sempre sobre o manto sacrificial que recobre a maternidade, a do sofrimento, a da abnegação. Não se estende ao grupo, à sociedade, tem sempre o coração materno como ponto de partida e chegada. Ela se choca quando Renata, a namorada que mora em São Paulo, aparece grávida, e pergunta-se logo sobre o sofrimento da mãe dela a respeito daquele mau passo. Fica perplexa em como podem existir pessoas que subvertem o bom andamento do sistema. Contudo, com quem ela poderia contar? Nem com a solidariedade das outras mulheres, a lhe farejarem a casa atrás de escândalo, a compararem os vestidos na missa de domingo, a maldizerem as filhas umas das outras, exercitando a maledicência contra elas, entre elas, para agradarem esse super-homem, essa entidade dona de todos os discursos aprovados pela sociedade. Falam para aumentarem o preço de si mesmas nesse mercado de escravas.

Maria Alice, de Jorginho, o machão (1970), Carminha, Mariangélica, de Vejo um vulto na janela, me acudam que sou donzela (1964), Dulce, de Lua nua (1987) e Mariana, Mariazinha e Melina, de Kuka - O segredo da alma de ouro (1980) são mulheres que ajudam a manter o sistema hegemonicamente masculino da sociedade, repetem os discursos misóginos sem refletir a respeito do que significam contra as mulheres, mas não podem ser acusadas de não perceberem que se trata de 
submissão. De certa forma, manipulam esse jogo, para que consigam entrar nesse jogo padrão de casar e ter marido e filhos, verdadeira guerra a que toda mulher deve se submeter para não fracassar nessa matriz social e evitar a queda na vala da histeria, onde são atiradas as mulheres que não foram capazes de conquistar um homem e, portanto, validar sua existência social.

DULCE: (firme) Patrão é quem não mexe no lixo. O seu Lúcio jámais limpou nem vai limpar o Júnior. Por isso ele me dispreza, mas eu respeito ele. A senhora, dona Sílvia, me desculpa, mas seu eu sou lixo, a senhora é tão lixo quanto eu (Lua nua, Assumpção, 2010, p. 422).

CARMINHA: Com eles tudo deu certo, nós progredimos, devíamos é seguir como estava indo antes, com ordem, cada um no seu lugar, os ricos de um lado e os pobres de outro, porque sempre vai haver ricos e pobres, sempre foi assim e sempre será. (Vejo um vulto na janela, me acudam que eu sou donzela, Assumpção, 2010, p. 41).

MALFADADA: Vocês não são mais minhas amigas! São más e são traiçoeiras! Vocês são amigas do rei! Do maldito rei Fernandez!

MELINA: O rei Fernando só quer o seu bem (Kuka - O segredo da alma de ouro, Assumpção, 2010, p. 316).

MARIA: Ora, tu tá acostumada com o batente.

JOANA: Só se tu tá acostumada com o meu batente, Maria, porque eu não tô não (Vejo um vulto na janela, me acudam que eu sou donzela, Assumpção, 2010, p. 71).

A exploração da mulher por outra mulher; o feminismo de Sílvia que não a impede de tratorar a mulher Dulce, sua empregada, duplamente refém por ser negra, e que, por sua vez, não a respeita por não ser homem; a colocação da sobrevivência feminina garantida pelo respeito vindo dos homens por seus comportamentos higienizantes, que ferem qualquer outra que se desvie das regras, é uma denúncia amarga de que o exercício da alteridade é um mecanismo complicado mesmo para os que atravessam as mesmas dificuldades. Esse ódio ressentido de mulher contra outra é resultado da impotência de se atingir o real opressor.

O ponto mais alto desse ressentimento está em Guta, de Adorável desgraçada (1994). Ela convive com o total fracasso de suas aspirações: estabilidade no emprego, o amor de um homem (que é 
assumidamente gay), os pequenos reconhecimentos diários, conforto material. Está em um limbo existencial cuja motivação maior é esperar notícias de Maribel, a amiga que conseguia tudo. Entretanto, as notícias deveriam vir com a derrocada dessa felicidade, sua ambição era ver o sucesso da outra desaparecer, vê-la na sarjeta, sozinha, assumindo junto com ela a incompetência de viver.

GUTA: Vou cortar o pulso, vou sumir... sumir... Será que pelo menos "isso" vai diminuir "um pouco" a (fecha os olhos) ininterrupta exuberância e felicidade da vida dela? Maldita! Será que nem assim ela vai sofrer, se machucar, cair de quatro, se arrastar? (Adorável desgraçada, Assumpção, 2010, p. 483).

Entretanto, nem Deus, em seu nome masculino, houve seu clamor. Como seria possível que alguém quebrasse todas as regras religiosas, familiares, morais e, ainda assim, conseguisse ser feliz e bem-sucedida? O que havia dado de errado com ela, que havia seguido direitinho o manual de ser uma boa mulher? Assim como Mariazinha, de Fala baixo senão eu grito (1969), Guta não quer atravessar essa porta, porque essa tomada de consciência demandará uma ação para a qual ela não está preparada, exigirá um esforço imenso para se reconstruir e se recolocar no mundo. Sem as ferramentas necessárias para isso, sem um manual que a ensine o que fazer, ela resolve o problema matando Maribel, fazendo desaparecer aquela que era a prova viva de que a ação e a coragem poderiam levar a mulher muito mais longe.

No meio do caminho, há aquelas que possuem o discurso da revolução, estereotipado, esvaziado de tanto ser repetido, mas a verdadeira mudança, a interna, essa está muito longe de acontecer. Renata, por exemplo, de Jorginho, o machão (1970), aparece na casa dos pais de Jorginho presunçosa e arrogante, como se fosse muito diferente de Maria Alice e Madalena; no entanto, ao perceber que Jorginho seria incapaz de qualquer atitude, se desespera. Praticamente vomita todo o seu desespero e medo de ter que enfrentar, mais que o confronto teórico, o desprezo real contra a mulher que não validou a burocracia institucional para se deitar com um homem. Os ideais românticos afloram, o homem ideal se delineia e, no medo maior, o anseio pela proteção masculina, pela infância que a acobertaria de enfrentar o mundo sem a tutela de um homem. 
É o mesmo caso de Reni, em Vejo um vulto na janela, me acudam que sou donzela (1964), que faz parte dos movimentos contra ditadura, mas se desencanta quando seu namorado a troca por outra companheira. Ao lecionar para o marido da empregada da pensão, apaixona-se por ele e leva um fora. Seu desabafo e sua revolta soam bem como um manifesto contra o preconceito, ora velado, ora escancarado, contra autoras que se atreveram a não falar da guerra proletária, e levanta a concepção de que o feminismo não pertence a nenhum lado político, posto que os direitos das mulheres não são pauta fundamental em nenhum deles.

No maior equilíbrio das forças, chega Intimidade indecente (2001), peça divertidíssima, que acompanha o envelhecimento de um ex-casal, cujo casamento se dissolveu pela traição de Mariano, que, em crise de meia idade, envolve-se com uma amiga da filha e se desinteressa sexualmente por sua esposa, Roberta. Reencontram-se a cada década para conversarem. Roberta denuncia a crueldade do mundo com seu "efeito sanfona" e com a velhice chegando e sendo recebida de formas totalmente diferentes para o homem e para a mulher. Não há panfleto ou dramas, mas as descobertas sexuais que ela vai fazendo durante seu trajeto, enquanto o ex-marido fica preso ao repetido esquema de encontrar e convencer uma mulher mais nova a ficar com ele.

Ela se relaciona com homens mais jovens e realça a importância de usufruir de sua experiência e de se renovar no contato íntimo com outras gerações, o que evidencia o aspecto de que esse personagem de Leilah coloca o sexo na clave do autoconhecimento, do gozo que é corpo e é entendimento do gozo. Em uma de suas experiências, mora com Léia, sua ex-terapeuta.

ROBERTA: A Léa é quase perfeita, "quase", por... Ah, se além de tudo o que ela é: companheira, solidária, se além de tudo o que ela tem também tivesse... o pau do Mariano!!!! (Intimidade indecente, Assumpção, 2010, p. 554).

Esse percurso do humor entrega uma mulher bem-humorada, independente, que, acima de qualquer teorização, resolveu experimentar, instruiu a si mesma com essa experiência e conseguiu avançar muito mais nisso que seu marido. É como se nela desabrochassem todas as outras mulheres anteriores a ela: viveu o casamento, os filhos, o abandono, a audácia sexual e recebeu a velhice rindo de si mesma. 


\section{Considerando o interlúdio}

Leilah Assumpção falou do humano, e esse humano era mulher e era homem, sem panfletagem, sem gritas ou maniqueísmos. Ela oferta, em seus trabalhos, apoio necessário para a leitura livre de rótulos, condescendências e aprisionamento das múltiplas faces que um texto pode assumir. $\mathrm{O}$ homem em busca de se saber dentro dos novos esquemas de relacionamentos, a mulher que enfrenta batalhas internas e guerra imensas com o mundo, estão todos ali, fazendo a humanidade avançar no redemoinho do saci, errante, em movimento, que avança e recua, mas sempre atuando, pelas forças internas, contra a dissolução. Ler obra de autora é ler uma obra. Que as mulheres autoras possam se beneficiar do que os autores homens já se beneficiam, de um leitor/espectador maleável ao que está por vir. E, mesmo assim, há que se dizer que Leilah cumpriu, em seus textos, com toda a agenda contemporânea do feminismo elencada por Margot Purjal em El feminismo como teoría (2015, p. 54), que são: a crise da masculinidade, a imersão dos homens nas tarefas domésticas, as violências de gênero, a crise da família patriarcal, a questão da maternidade, a paternidade afetiva, o assédio sexual e laboral, a imigração de mulheres, o feminismo em relação a outros movimentos, a articulação entre diferentes posicionamentos dentro do feminismo entre outros.

\section{Referências}

ANDRADE, Ana Lúcia Vieira de (2006). Margem e centro. São Paulo: Perspectiva. ANDRADE, Ana Lúcia Vieira de; EDELWEISS, Ana Maria de Bulhões Carvalho (Org.) (2008). A mulher e o teatro brasileiro do século XX. São Paulo: Hucitec.

ARAÚJO, Laura Castro de (2007). A dramaturgia de autoria feminina. In: SEMINÁRIO NACIONAL MULHER E LITERATURA, 12.; e SEMINÁRIO INTERNACIONAL MULHER E LITERATURA, 3., 9-11 out. 2007, Uesc, Ilhéus. Anais... Ilhéus: Uesc.

ASSUMPÇÃO, Leilah (2010). Onze peças de Leilah Assumpção. Rio de Janeiro: Casa da Palavra.

BAUMAN, Zygmunt (2005). Identidade. Entrevista a Benedetto Vecchi. Tradução de Carlos Alberto Medeiros. Rio de Janeiro: Zahar. E-book. 
CARPEAUX, Otto Maria (2011). História da literatura ocidental. São Paulo: Leya. E-book.

CLARO, Priscilla (2015). Uma leitura crítica de Fala baixo, senão eu grito, de Leilah Assumpção. Dissertação (Mestrado em Literatura Brasileira) - Universidade de São Paulo, São Paulo.

MAGALDI, Sábato (2004). Panorama do teatro brasileiro. São Paulo: Global, 2004.

MAGALDI, Sábato (2008). O texto no teatro. São Paulo: Perspectiva, 2008.

MAGALDI, Sábato (2015). Amor ao teatro. Pesquisa, seleção e organização Edla Van Steen. São Paulo: Sesc. E-book.

MATE, Alexandre; SCHWARCZ, Pedro M. (Org.) (2012). Antologia do teatro brasileiro. Rio de Janeiro: Cia das Letras.

PATRIOTA, Rosangela; GUINSBURG, Jacó (2012). Teatro brasileiro: ideias de uma história. São Paulo: Perspectiva.

PELLEGRINI, Sandra (2007). A representação dos papéis e da sexualidade feminina no teatro brasileiro durante o período da ditadura militar. Diálogos, Costa Rica, v. 8, n. 1, p. 270-289, febr./sept.

PONTES, Heloísa (2013). Mariazinha e Verônica: classe e gênero nos palcos da metrópole. Novos Estudos - Cebrap, São Paulo, n. 97, p. 149-166, nov.

PRADO, Décio Almeida (2009). O teatro brasileiro moderno. São Paulo: Perspectiva.

PRIORE, Mary Del (2012). História do amor no Brasil. São Paulo: Contexto. Ebook.

PUJAL, Margot (2015). El feminismo como teoría. Barcelona: UOC. E-book.

ROMANO, Lúcia Regina Vieira (2009). De quem é esse corpo? - A performatividade do feminino no teatro contemporâneo. Tese (Doutorado em Teoria e Prática do Teatro) - Universidade de São Paulo, São Paulo.

ROSENFELD, Anatol (2014). Teatro em crise. São Paulo: Perspectiva.

TRIGUEROS, Maria Tereza Alario (2008). Arte y feminismo. San Sebastian: Nerea. E-book.

VINCENZO, Elza Maria de (1992). Um teatro da mulher. São Paulo: Perspectiva.

Recebido em 10 de janeiro de 2017.

Aprovado em 26 de maio de 2017. 


\section{resumo/abstract/resumen}

\section{Leilah Assumpção, os muros e o dia branco}

Fernanda Ribeiro Queiroz de Oliveira

Leilah Assumpção é uma dramaturga cujas peças não recebem a atenção necessária nem da crítica especializada, nem do mercado editorial, ambiente ainda vascularizado pelo machismo e pelas arquiteturas que engendram as posições de direção e escrita de teatro como masculinas. Representante da nova dramaturgia que floresceu a partir da década de 1970, a dramaturga traça uma mandala em que os relacionamentos surgem como tema engendrados pela busca de visibilidade pela mulher, dos seus anseios pessoais, sexuais e profissionais e da consequente desestabilização dos papéis tradicionalmente atribuídos aos homens. Este artigo analisa a obra de Leilah Assumpção, mostrando como, usando de um tratamento irônico e inesperadamente bem humorado em situações de alta tensão, a autora trabalha a saga de seres humanos em encontrarem a si mesmos dentro do mundo.

Palavras-chave: Leilah Assumpção, gênero, dramaturgas, misoginia, mulheres.

\section{Leilah Assumpção, the wall and the neutral day}

Fernanda Ribeiro Queiroz de Oliveira

Leilah Assumpção's plays have not received neither the critical nor the editorial attention they merit, this lack of attention is the result of an environment dominated by misogyny and by power structures that construe dramaturgy and writing as typically male activities. Being part of a new dramaturgy, which flourished in the seventies, the playwright draws a path where relationships emerge as the search for women's visibility, the visibility of their personal, sexual and professional desires and, therefore, the questioning of traditional male roles. This article analyses Assumpção's work, showing how through an ironic and unexpectedly humorous depiction of highly conflicted situations she presents the subject's journey towards their selves and their places in the world.

Keywords: Leilah Assumpção, gender, playwright, misogyny, women.

\section{Leilah Assumpção, os muros e o dia branco}

Fernanda Ribeiro Queiroz de Oliveira

Leilah Assumpção es una dramaturga cuyas piezas no reciben la atención necesaria ni de la crítica especializada, ni del mercado editorial, ambiente aun vascularizado por el machismo y por las arquitecturas que engendran las posiciones de dirección y escritura de teatro como masculinas. Representante de 
la nueva dramaturgia que floreció a partir de la década de 1970, la dramaturga traza una mandala en la que las relaciones surgen como tema engendrados por la búsqueda de visibilidad de la mujer, de sus anhelos personales, sexuales y profesionales y de la consiguiente desestabilización de los papeles tradicionalmente atribuidos a los hombres. Este artículo analiza la obra de Leilah Assumpção, mostrando cómo, usando un tratamiento irónico e inesperadamente lleno de humor en situaciones de alta tensión, la autora trabaja la saga de seres humanos encontrándose a sí mismos dentro del mundo.

Palabras clave: Leilah Assumpção, género, dramaturgas, misoginia, mujeres. 